\title{
Ethylene bis (diphenylphosphine)
}

\author{
提案者 野平博之, 谷口守正, 島村喜一 \\ (埼玉大学理工学部) \\ $2\left(\mathrm{C}_{6} \mathrm{H}_{5}\right)_{2} \mathrm{POC}_{2} \mathrm{H}_{5} \underset{2 \times 23.0}{\stackrel{2 \mathrm{Na}}{\longrightarrow}} 2\left(\mathrm{C}_{6} \mathrm{H}_{5}\right)_{2} \mathrm{PNa} \underset{98.9}{\stackrel{\mathrm{ClCH}_{2} \mathrm{CH}_{2} \mathrm{Cl}}{\longrightarrow}}\left(\mathrm{C}_{6} \mathrm{H}_{5}\right)_{2} \mathrm{PCH}_{2} \mathrm{CH}_{2} \mathrm{P}\left(\mathrm{C}_{6} \mathrm{H}_{5}\right)_{2}$ \\ $2 \times 230.2$ \\ 398.4
}

I. 製 法

還流冷却器, 滴下漏斗, 窒素流入口および気密かきまぜ機（注意 1 ）を付した $500 \mathrm{ml}$ の四つ口フラスコに無水ジオキ サン $100 \mathrm{ml}$ ，金属ナトリウム $2.8 \mathrm{~g}\left(0.122 \mathrm{~g}\right.$-atom) を入れ窒素気流中で油浴の温度を $120 \sim 130^{\circ} \mathrm{C}$ に保ち，激しくか きまぜてナトリウムを分離させる。つぎに，ジオキサン $25 \mathrm{ml}$ に溶かした ethyl diphenylphosphinite $12.5 \mathrm{~g}$ (0.054 $\mathrm{mol}$ ） 40～50 分かけて滴下する。反応液は黄色になり，さらに 3.0 3.5 時間かきまぜながら加熱を続けるとオレ ンジ色になる。これを約 $10^{\circ} \mathrm{C}$ に泠却し，ジオキサン $15 \mathrm{ml}$ に溶かした 1,2 -ジクロルエタン $2.7 \mathrm{~g}(0.027 \mathrm{~mol})$ を 34 40 分かけてゆっくり滴下すると反応液はしだいに黄白色になる。さらに 1.0 1.5 時間反応させた後, 水水で 冷却しながら水 $150 \mathrm{~m} l$ を滴下すると白色結晶が析出する。これを吸引口過し（注意 2 ), 水でよく洗った後，デシケ 一ター中で乾燥すると粗結晶 9.8 10.1 g (91.2〜 94.0\%) を得る。シクロヘキサン $130 \mathrm{~m} l$ で再結晶すると $\mathrm{mp} 140$ ～ $141^{\circ} \mathrm{C}$ の純品 $7.6 \sim 8.4 \mathrm{~g}(70.7 \sim 78.1 \%)$ が得られる。

なお，同様にして 1,2-ジクロルエタンの代りに一般式 $\mathrm{Cl}\left(\mathrm{CH}_{2}\right)_{\mathrm{n}} \mathrm{Cl}(\mathrm{n}=1 \sim 5)$ で表わされるジクロルアルカンを用 いれば一連のアルキレンビスジフェニルホスフィン $\left(\mathrm{C}_{6} \mathrm{H}_{5}\right)_{2} \mathrm{P}\left(\mathrm{CH}_{2}\right)_{\mathrm{n}} \mathrm{P}\left(\mathrm{C}_{6} \mathrm{H}_{5}\right)_{2}(\mathrm{n}=1$ 1 5) を合成することができる。 次に $\mathrm{n}=2$ 以外のホスフィンの融点および再結晶溶媒を示す。 $\mathrm{n}=1, \mathrm{mp} 118.0 \sim 120.0^{\circ} \mathrm{C}$ (シクロヘキサン); $\mathrm{n}=3$, $\mathrm{mp} 60.5 \sim 62.0^{\circ} \mathrm{C}$ (石油エーテル); $\mathrm{n}=4, \mathrm{mp} \mathrm{129.0 \sim 130.5^{ \circ } \mathrm { C } \text { (シクロヘキサン) } \mathrm { n } = 5 , \mathrm { mp } 4 4 . 0 \sim 4 5 . 0 ^ { \circ } \mathrm { C } ( \times タ ) ー ~}$ ル洗浄)

\section{II. 注意 事項}

(1) Hershberg のかきまぜ棒を用いるのが好ましい。

(2) 悪臭をもち, 毒性の強いジフェニルホスフィン $\left(\mathrm{C}_{6} \mathrm{H}_{5}\right)_{2} \mathrm{PH}$ が副生しているので吸入しないように注意する。

\section{III. 性質}

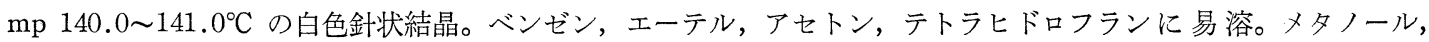
エタノールに難溶。水に不溶。塩化コバルト，塩化ニッケルなどと錯化合物をつくる。

\section{IV. 本法の利点}

従来，下記のような合成方法が知られている。

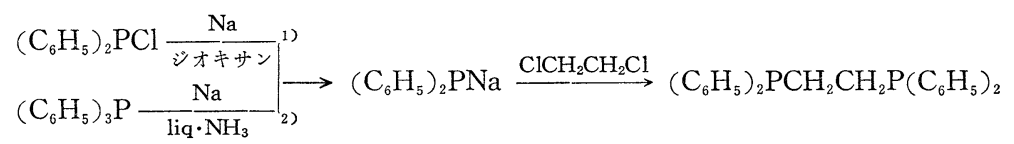

前者は比較的合成が煩雑な diphenylphosphinous chloride を用いるものであり, 後者は液体アンモニアを用いるとい う煩雑さがある。本法は前項で提案したように実験室的に比較的合成し易い diphenylphosphinite を用いジオキサン中 でナトリウムジフェニルホスフィドを調製し，以下既知の方法に準じて標記化合物に導くものである。

\section{引用文献}

1) K. Issleib, D.W. Müller, Ber. 923175 (1959)

2) W. Hewertson, H.R. Watson, J. Chem. Soc. 19621490 